\title{
Numerical simulation of the flow over a tubercled wing
}

\author{
Mohammed Baghdad ${ }^{1, *}$, Abdelkader Nehmar ${ }^{1}$, and Ahmed Ouadha ${ }^{2}$ \\ ${ }^{1}$ Institut des Sciences et Technologie, Centre Universitaire El-Wancharissi de Tissemsilt, B.P. 182, 38000 Tissemsilt, Algérie \\ ${ }^{2}$ Laboratoire des Sciences et Ingénierie Maritimes, Faculté de Génie Mécanique, Université des Sciences et de la Technologie \\ Mohamed Boudiaf d'Oran, Oran El-M'nouar, 31000 Oran, Algérie
}

\begin{abstract}
The objective of the present study is to carry out a numerical study of the flow around a NACA0021 modified wing by the incorporation of sinusoidal tubercles on its leading edge at a Reynolds number equal to 225,000 . The SST $k-\omega$ turbulence model is used as closure to the incompressible governing equations. Runs have been performed for several attack angles. Results show that for lower angles of attack, tubercles reduce the drag coefficient with a slight increase in lift.
\end{abstract}

\section{Introduction}

Fauna and flora have always inspired humankind in their inventions and problem solving. Several technologies in all fields of science have been developed by the observation of nature. This approach, known also as biomimetic, has been widely adopted in the design of submarines and marine propellers in order to reduce drag. In particular, the performance of airfoils can be improved by generating streamwise vortices in boundary layer using tubercled leading edge inspired by prior studies carried out by marine biologists on the morphology of humpback whales pectoral flippers [1-2]. They demonstrated that the high aspect ratio with large sinusoidal tubercles along the flipper leading edge can cause a considerable increase in the stall angle of attack and the maximum lift coefficient.

Several studies have been performed on tubercled leading edge wings during the last years. In particular, experimental studies have demonstrated their benefits. Generally, in most studies, the utilization of airfoils with tubercled leading edge showed improved performance in terms of lower drag, higher lift and shorter separation region. However, in some studies, it is found an opposite trend. Experimental studies aimed to measure lift, drag and pitching moments for various attack angles in wind tunnels. Results are generally analyzed by varying amplitude and wavelength of tubercles. Table 1 summarizes previous experimental studies on tubercled wings.

Recent applications of CFD to solve the Navier-Stokes equations for tubercled wings are summarized in Table 2. In most of studies, in-house research codes that are rarely available for researchers have been used. It is more convenient to perform studies in this topic using available commercial CFD codes such as Fluent. The latter can solve laminar and turbulent, incompressible and compressible, 2D and 3D, steady and unsteady flows.
The conflicting findings observed in the literature regarding the effect of tubercles on the performance of wings make this topic a challenging subject. Further studies are necessary and the present paper constitutes one.

\section{Mathematical model}

Two NACA 0021 wings designed, built and tested by Bolzon et al. [21] have been used in the present study. One wing had a smooth leading edge, whereas the other wing had tubercles with amplitude of $10.5 \mathrm{~mm}$ and a wavelength of $60 \mathrm{~mm}$ along its entire leading edge as depicted in Figure 1. Both wings had a span of $330 \mathrm{~mm}$, a Mean Aerodynamic Chord of $130 \mathrm{~mm}$ and a taper ratio of 0.4 . a.

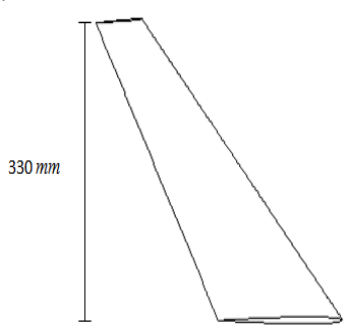

$b$

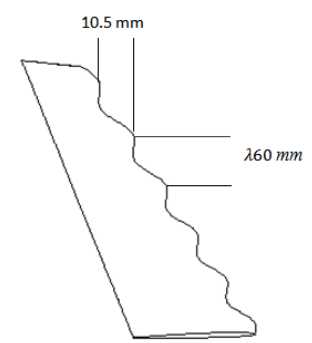

Fig. 1. Geometry of wings studied : $a$. Conventional wing ; $b$. Tubercled wing

The three-dimensional, incompressible and steady Reynolds averaged Navier-Stokes equations are given below:

$$
\begin{gathered}
\frac{\partial \bar{u}_{i}}{\partial x_{i}}=0 \\
\frac{\partial\left(\bar{u}_{i} \bar{u}_{j}\right)}{\partial x_{j}}=-\frac{1}{\rho} \frac{\partial \bar{p}}{\partial x_{i}}+v \frac{\partial^{2} \bar{u}_{i}}{\partial x_{j}^{2}}+\frac{1}{\rho} \frac{\partial \bar{R}_{i j}}{\partial x_{j}}+\bar{g}_{i}
\end{gathered}
$$

\footnotetext{
* Corresponding author: baghdad.cut@gmail.com
} 
Table 1. Previous experimental studies on tubercled wings

\begin{tabular}{|c|c|c|c|c|c|}
\hline Reference & Profile & $A / c$ & $\lambda / C$ & $\operatorname{Re}$ & $\alpha$ \\
\hline Miklosovic et al. [4] & NACA 0020 & I & l & $5.05 \times 10^{5}-5.20 \times 10^{5}$ & $-2 \div 20^{\circ}$ \\
\hline $\begin{array}{l}\text { Miklosovic and al. } \\
\text { [5] }\end{array}$ & NACA 0020 & 0.04 & l & $274,000-277,000$ & $-2 \div 20^{\circ}$ \\
\hline Johari and al. [6] & NACA $634-021$ & $\begin{array}{c}0.025,0.05 \\
0.12\end{array}$ & $0.25,0.5$ & $1.83 \times 10^{5}$ & $-6 \div 30^{\circ}$ \\
\hline Hansen and al. [7] & NACA 0021 & $0.03 \div 0.11$ & $0.11 \div 0.43$ & $1.2 \times 10^{5}$ & $0 \div 20^{\circ}$ \\
\hline Hansen and al. [8] & $\begin{array}{l}\text { NACA } 0021 \\
\text { NACA65-021 }\end{array}$ & $0.028 \div 0.114$ & $0.1 \div 0.43$ & $1.2 \times 10^{5}$ & $0 \div 25^{\circ}$ \\
\hline $\begin{array}{c}\text { Guerreiro and } \\
\text { Souse [9] }\end{array}$ & $\begin{array}{l}\text { NASA LS(1)- } \\
0417\end{array}$ & $0.06,0.12$ & $0.25,0.5$ & $\begin{array}{l}1.4 \times 10^{5} \\
0.7 \times 10^{5}\end{array}$ & $0 \div 30^{\circ}$ \\
\hline Hansen and al. 10] & NACA 0021 & $0.03 \div 0.11$ & $0.11 \div 0.43$ & $1.2 \times 10^{5}$ & $1 \div 8^{\circ}$ \\
\hline Chen and al. [11] & $\begin{array}{c}\text { FLAT-PLATE } \\
E=3 \mathrm{MM}\end{array}$ & $2.5,5,12$ & $0.16,0.21,0.31$ & $2.7 \times 10^{5}$ & I \\
\hline $\begin{array}{l}\text { Sudhakar and } \\
\text { Karthikeyan [12] }\end{array}$ & NACA 4415 & 0.1 & 0.25 & $1.2 \times 10^{5}$ & $6^{\circ}$ \\
\hline Zverkov and al. [13] & Z 15-25 & 0.01 & 0.12 & $\begin{array}{l}1.2 \times 10^{5} \\
1.4 \times 10^{5}\end{array}$ & $-20 \div 20^{\circ}$ \\
\hline Bolzon and al. [14] & NACA 0021 & 0.0233 & 0.174 & $2.2 \times 10^{5}$ & $-2 \div 10^{\circ}$ \\
\hline Keerthi and al. [15] & NACA65209 & $0.033,0.067$ & $0.083,0.0125$ & / & $\begin{array}{c}-5,-3,1,5,9,13, \\
17^{\circ}\end{array}$ \\
\hline $\begin{array}{c}\text { Custodio and al. } \\
{[16]}\end{array}$ & NACA634-021 & $\begin{array}{l}0.025,0.05 \\
\quad 0.12\end{array}$ & $0.25,0.5$ & $9 \times 10^{4} \div 4.5 \times 10^{5}$ & $0 \div 30^{\circ}$ \\
\hline Wei and al. [17] & NACA634-021 & $\begin{array}{c}0.025,0.05 \\
0.12\end{array}$ & $0.25,0.5$ & $1.4 \times 10^{4}$ & $0,10,15,20^{\circ}$ \\
\hline Wei and al. [18] & SD7032 & 0.12 & 0.5 & $1.4 \times 10^{4}$ & $15^{\circ}$ \\
\hline $\begin{array}{c}\text { Bolzon and al. } \\
\text { [19-20-21] }\end{array}$ & NACA 0021 & $\mathrm{~A}=10.5$ & $\Lambda=60$ & $2.25 \times 10^{5}$ & / \\
\hline Keerthi and al. [22] & NACA 65209 & $0.033,0.066$ & $0.125,0.166$ & $1.3 \times 10^{5}$ & $-5 \div 20^{\circ}$ \\
\hline Wei and al. [23] & NACA634-021 & 0.12 & 0.25 & l & $0,10,15,20^{\circ}$ \\
\hline Qiao and Tong [24] & NACA 0012 & $0.025,0.05,0.1$ & $0.1,0.2,0.4$ & $2 \div 8 \times 10^{5}$ & $0,5,10,15^{\circ}$ \\
\hline Peristy and al. [25] & NACA 0018 & $\begin{array}{c}0.03,0.04,0.05 \\
0.06\end{array}$ & $\begin{array}{c}0.11,0.13,0.18, \\
0.21\end{array}$ & $\begin{array}{c}7.5 \times 10^{4}, 1.5 \times 10^{5}, \\
3 \times 10^{5}\end{array}$ & $0 \div 30^{\circ}$ \\
\hline
\end{tabular}

The Reynolds stress tensor $\bar{R}_{i j}$ is approximated using one of the different turbulence models provided in the CFD commercial software Fluent. A careful analysis of the literature reveals that there is no agreement on the selection of turbulence models in the analysis of the flow around tubercled wings. However, it seems that SST $k-\omega$ provides better performance in predicting the flow structure around a tubercled wing.

The computational domain has been created according to experiments by Bolzon et al. [21] in a wind tunnel. The domain has an inlet section of $0.5 \times 0.5 \mathrm{~m}$ and a length of $2.2 \mathrm{~m}$. The wing is placed at a distance of $0.45 \mathrm{~m}$ from the inlet.

The domain has been meshed using a multi block technique. A block represented by a cylinder containing the wing to allow its rotation in order to obtain the desired angle of attack and a second block for the remaining domain. Figure 2 depicts an overview the computational domain.

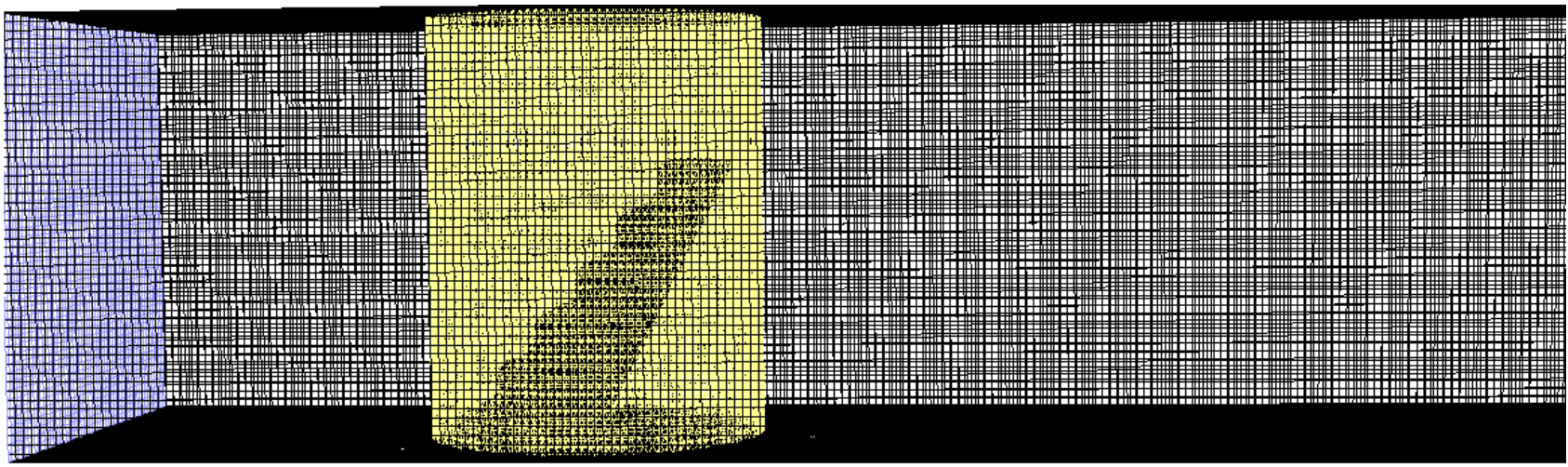

Fig. 2. Computational domain meshing

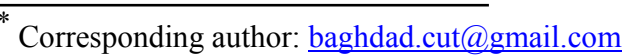


The steady Reynolds averaged Navier-Stokes equations, the turbulence model equations and the corresponding boundary conditions have been numerically solved using the pressure based solver of the commercial $C F D$ code Fluent. A second order upwind scheme has been selected to discretize momentum and turbulence terms. The algorithm PRESTO is used to compute the coupling between the pressure and the velocity field. The runs were assumed to reach convergence once the residuals fall below the value of $10^{-6}$ for all variables.

Table 2. Previous numerical studies on tubercled wings

\begin{tabular}{|c|c|c|c|c|c|c|c|}
\hline Reference & Profile & $A / c$ & $\lambda / C$ & $\operatorname{Re}$ & $\bar{\alpha}$ & Turb. & Code \\
\hline Favier and al. [26] & NACA0020 & $0 \div 0.1$ & $0.25 \div 2$ & 800 & 20 & I & In-house \\
\hline $\begin{array}{c}\text { Swanson and Isaak } \\
{[27]}\end{array}$ & $\begin{array}{c}\text { NACA } 634- \\
021 \\
\text { NACA0020 }\end{array}$ & $\begin{array}{c}0,2.5,5 \\
10 \%\end{array}$ & $\begin{array}{c}0,4 \mathrm{ET} \\
8\end{array}$ & $\begin{array}{l}1.8 \times 10^{5} \\
6.3 \times 10^{5}\end{array}$ & $\begin{array}{l}0^{\circ}, 4^{\circ}, \\
8^{\circ}, 12^{\circ}\end{array}$ & / & Fluent \\
\hline Zhang and $\mathrm{Wu}[28]$ & S809 & $\begin{array}{c}0.0125- \\
0.0375\end{array}$ & $\begin{array}{c}0.17- \\
0.42\end{array}$ & $\begin{array}{c}\text { Wind speed } \\
7-10-15-20-25 \\
\mathrm{M} / \mathrm{S}\end{array}$ & / & $S-A$ & Fluent \\
\hline Feng and al. [29] & NACA0020 & 0.0442 & 1.32 & $1.35 \times 10^{5}$ & $0 \div 26^{\circ}$ & $k-\varepsilon R N G$ & In-house \\
\hline Kim and al. [30] & NACA0020 & 0.05 & $\begin{array}{c}0.75 \\
0.375 \\
0.25 \\
0.1875\end{array}$ & $10^{6}$ & $0 \div 40^{\circ}$ & $k-\varepsilon$ Realizable & Fluent \\
\hline Lohry and al. [31] & NACA0020 & 0.05 & 0.4 & $5 \times 10^{5}$ & $0 \div 20^{\circ}$ & $\begin{array}{l}S-A \\
S S T\end{array}$ & In-house \\
\hline Abdel Gawad [32] & NACA0012 & 0.05 & 0.2 & $10^{6}$ & $0 \div 20^{\circ}$ & $k-\varepsilon$ & In-house \\
\hline Câmara and al. [33] & $\begin{array}{c}\text { NASA } \\
\text { LS(1)-0417 }\end{array}$ & 0.12 & 0.5 & $1.6 \times 10^{5}$ & $0 \div 20^{\circ}$ & $k-\omega S S T$ & In-house \\
\hline Corsini and al. [34] & $\begin{array}{l}\text { NACA0015 } \\
\text { NACA4415 }\end{array}$ & 0.025 & 0.25 & $1.83 \times 10^{5}$ & $0 \div 30^{\circ}$ & $k-\varepsilon$ & In-house \\
\hline Lau and al. [35] & NACA0015 & & & $3.6 \times 10^{5}$ & $-1 \div 4^{\circ}$ & & In-house \\
\hline Skillen and al. [36] & NACA0021 & 0.015 & 0.21 & $1.2 \times 10^{5}$ & $20^{\circ}$ & LES & In-house \\
\hline Xingwei and al. [37] & NACA0014 & $0.05-0.1$ & $0.25-0.5$ & $10^{4}$ & $0 \div 15^{\circ}$ & $k-\omega S S T$ & In-house \\
\hline $\begin{array}{c}\text { Aftab and Ahmed } \\
{[38]}\end{array}$ & NACA4415 & $\begin{array}{l}\text { Spherical } \\
\text { tubercles }\end{array}$ & $\begin{array}{c}\mathrm{D}=0.1- \\
0.2\end{array}$ & $2.5 \times 10^{5}$ & $0 \div 20^{\circ}$ & $S A$ & $\begin{array}{c}\text { Ansys } \\
14.5\end{array}$ \\
\hline Asli and al. [39] & S809 & 0.025 & 0.25 & $10^{6}$ & $0 \div 20^{\circ}$ & $D E S-S S T k-\omega$ & In-house \\
\hline Cai and al. [40] & $\begin{array}{c}\text { NACA634- } \\
021\end{array}$ & $0.025-0.12$ & 0.5 & $1.83 \times 10^{5}$ & $0 \div 30^{\circ}$ & $S A$ & Fluent \\
\hline Joy and al. [41] & $\begin{array}{c}\text { NACA634- } \\
021\end{array}$ & 0.12 & $0.25-0.5$ & $1.4 \times 10^{4}$ & $0 \div 15^{\circ}$ & $k-\omega S S T$ & Fluent \\
\hline $\begin{array}{c}\text { Serson and. } \\
\text { Meneghini [42] }\end{array}$ & NACA0012 & $0 \div 0.2$ & $0.25 \div 1$ & 1000 & $0 \div 21^{\circ}$ & / & In-house \\
\hline Cai and al. [43] & $\begin{array}{c}\text { NACA 634- } \\
021\end{array}$ & $\begin{array}{l}\text { SINGLE } \\
\text { LEADING- } \\
\text { EDGE }\end{array}$ & 0.25 & $10^{5}$ & $3 \div 24^{\circ}$ & $S A$ & Fluent \\
\hline $\begin{array}{c}\text { Kobæk and Hansen } \\
{[44]}\end{array}$ & S809 & 0.015 & 0.125 & $10^{6}$ & $-2 \div 24^{\circ}$ & $k-\omega S S T$ & $\begin{array}{l}\text { Star } \\
\mathrm{ccm}+\end{array}$ \\
\hline $\begin{array}{c}\text { Rostamzad and al. } \\
{[45]}\end{array}$ & NACA0021 & 0.028 & 0.1 & $\begin{array}{c}0.12 \times 10^{6} \\
1.5 \times 10^{6}\end{array}$ & $0 \div 20^{\circ}$ & $k-\omega S S T$ & CFX \\
\hline Zhang and al. [46] & $\begin{array}{c}\text { NACA 634- } \\
021\end{array}$ & 0.24 & 0.25 & $2 \times 10^{5}$ & $\begin{array}{c}6,12,18,24,4 \\
5^{\circ}\end{array}$ & $D E S$ & In-house \\
\hline Benaissa and al. [47] & $\begin{array}{c}\text { NACA 634- } \\
021\end{array}$ & 0.12 & 0.5 & $1.4 \times 10^{4}$ & $0 \div 20^{\circ}$ & $k-\omega S S T$ & $\begin{array}{l}\text { Ansys } \\
17.0 .\end{array}$ \\
\hline $\begin{array}{l}\text { Pérez-torró and Kim } \\
{[49]}\end{array}$ & NACA0021 & 0.03 & 0.11 & $1.2 \times 10^{5}$ & $20^{\circ}$ & LES & In-house \\
\hline Zhao and al. [49] & $\begin{array}{c}\text { NACA 634- } \\
021\end{array}$ & 0.12 & 0.25 & $2 \times 10^{5}$ & $0 \div 60^{\circ}$ & $D E S$ & $\begin{array}{l}\text { /In- } \\
\text { house }\end{array}$ \\
\hline
\end{tabular}

\section{Results}

The results of the simulations are presented as follows. First, a mesh independency test has been performed in order to ensure that the numerical solution is independent to the size of the grid used. This operation is then followed by a detailed analysis of the flow around the wings in terms of lift coefficient, drag coefficient and streamlines. The results have been plotted at Reynolds number of 0.225 million for angles of attack ranging from 0 to $20^{\circ}$.

\subsection{Mesh independency test}

A mesh independency test has been performed. Three grids of 1 million, 2 million and 4 million have been used for angles of attack ranging from 0 to $20^{\circ}$ at a Reynolds number of 0.225 million. Figure 3 shows a comparison of lift and drag coefficients obtained using

\footnotetext{
* Corresponding author: baghdad.cut@gmail.com
} 
the three grids. It is observed that similar values are obtained using grids 2 and 3. Thus, results are obtained using a mesh of 2 million cells.

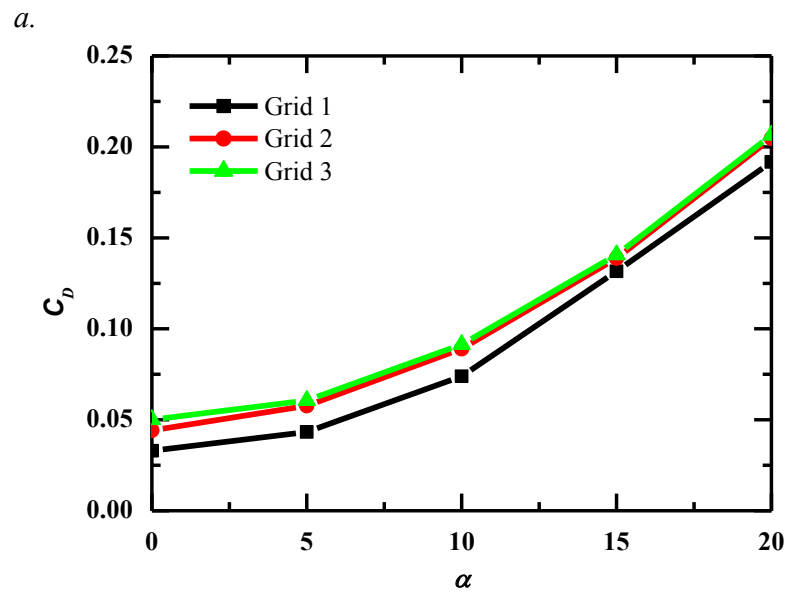

b.

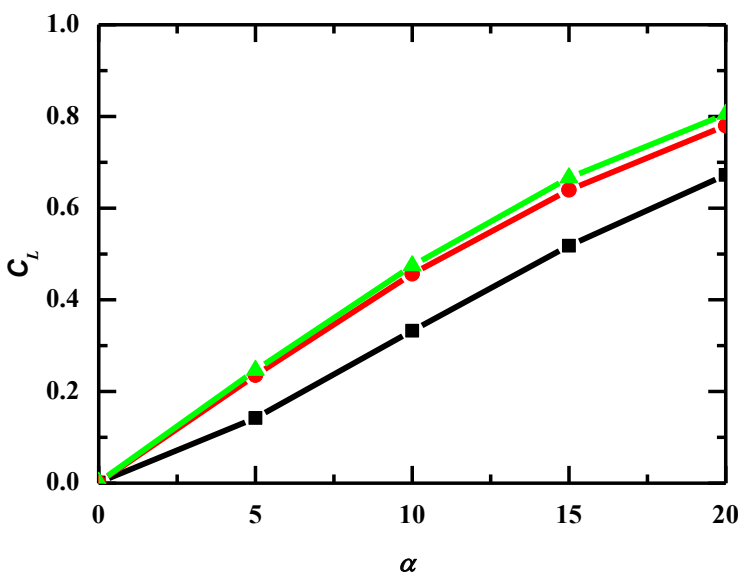

Fig. 3. Mesh independency test: $a$. drag coefficient; $b$. lift coefficient

\subsection{Lift and drag coefficients}

The effect of the angle of attack on the lift and drag coefficients of wings with smooth and tubercled leading edges is presented in Figure 4. Both lift and drag coefficients increase as the angle of attack increases. For both experimental and numerical data, at lower angles of attack, leading edge tubercles produce lift coefficient slightly greater than smooth leading edge. The difference increases as the angle of attack increases. As stated by many researchers, this trend can be attributed to the formation of a laminar separation bubble on the section side of the wings [10-20, 45]. However, there is no widespread agreement on this finding. The laminar separation bubble on the section side of wings have not been observed by other researchers $[4,6]$.

For lower angles of attack ( $\alpha<8$ (for experimental measurement) and $\alpha<12$ (for numerical data)), tubercles reduce the drag coefficient as illustrated in Figure 3.b. However, for angles of attack greater than these values, tubercles increase the drag coefficient.
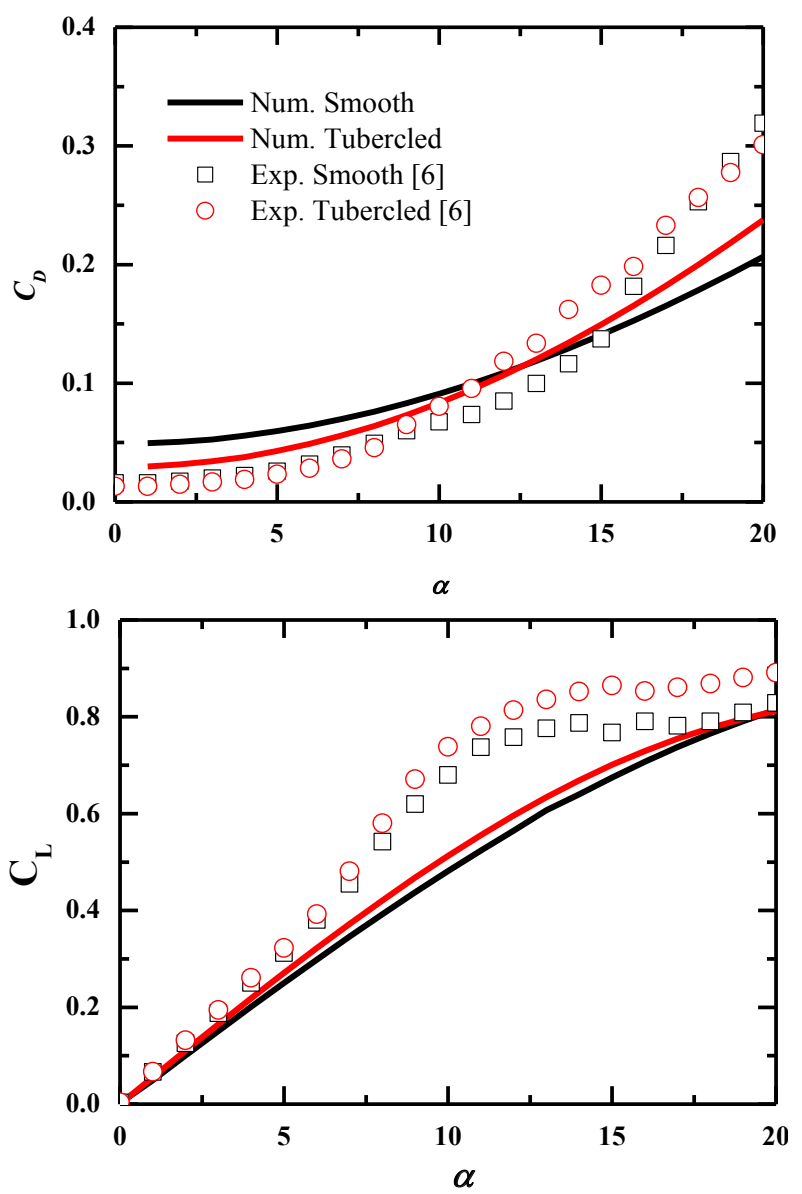

Fig. 4. Effect of the angle of attack on the lift and drag coefficients

\subsection{Streamlines}

Figure 4 gives a comparison between streamlines colored by the flow velocity obtained for tubercled and smooth wings at angles of attack of 0,10 and $20^{\circ}$. For $\alpha$ $=0$ and $10^{\circ}$, the streamlines behind the wings remain parallel to the free stream. However, the pattern of streamlines at $\alpha=20^{\circ}$ is modified with the formation of vortices.

\section{Conclusions}

The flow around two swept wings, one smooth and one tubercled, has been numerically analyzed using the commercial code Fluent. Turbulence has been modeled using SST $k$ - $\omega$ model, the most widely used model for this kind of flows. It is found that for lower angles of attack, tubercles reduce the drag coefficient with a slight increase in lift.

The discrepancy between numerical results and experimental measurements at attack angles greater than 5 cannot be attributed to experimental errors as it is observed for both wings. Indeed, under these conditions, laminar separation bubble on the section side of the wings observed in many previous experimental studies appears and SST $k-\omega$ model falls in predicting correctly the airfoil's pressure distribution. 
a.
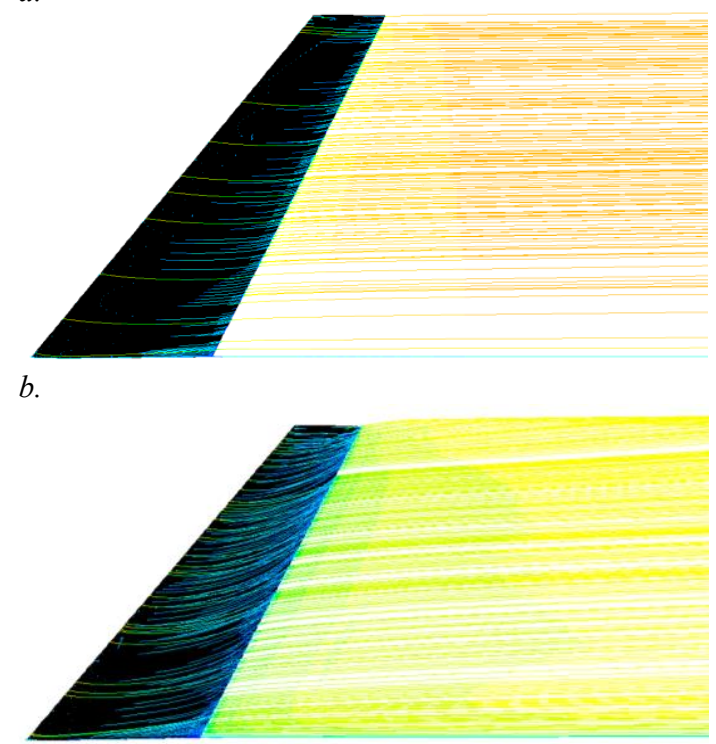

$c$.

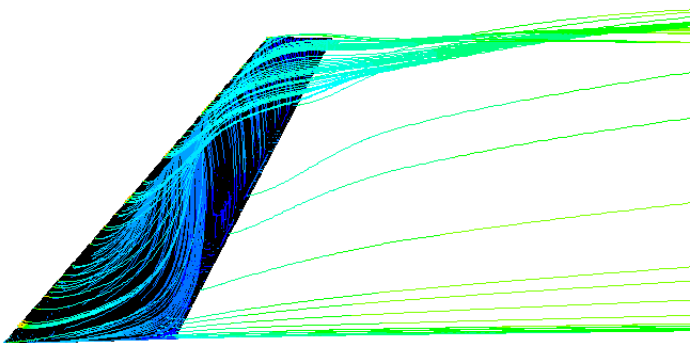

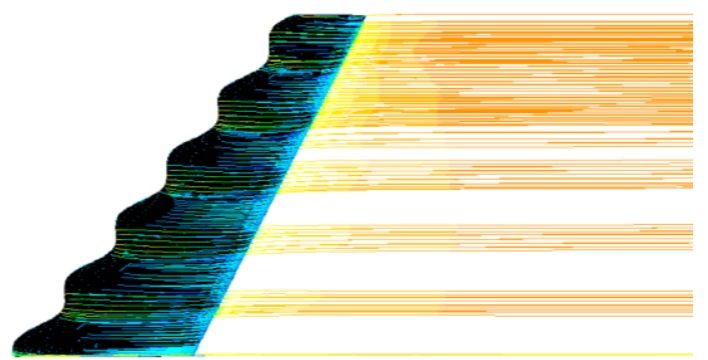
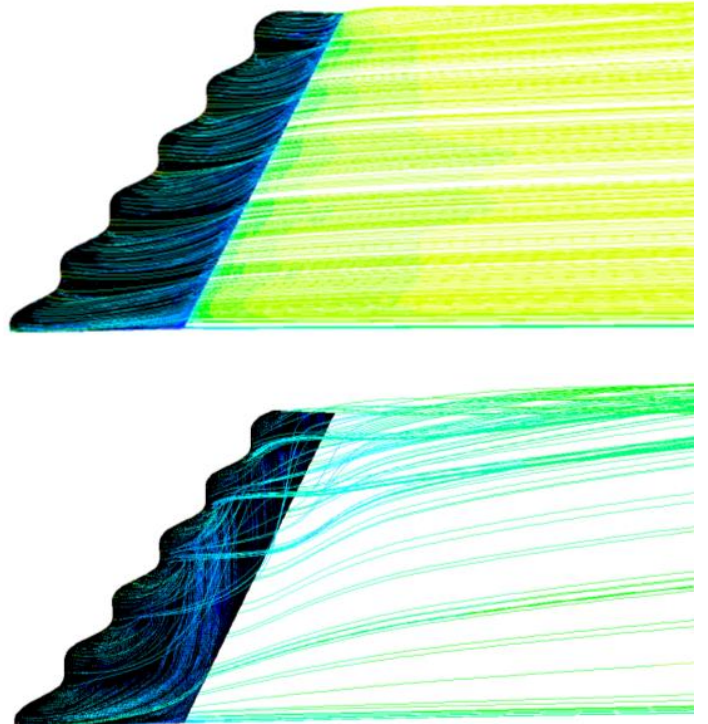

Fig. 5. Streamlines colored by the velocity at an angle of attack angle: $a . \alpha=0^{\circ}, b .10^{\circ}, c .20^{\circ}$

\section{References}

1. F.E. Fish, J.M. Battle, J. Morphology, 225 (1995)

2. F.E. Fish, New Hampshire, 1999

3. K.L. Hansen, Effect of leading edge tubercles on airfoil performance. Ph.D. Dissertation, The School of Mechanical Engineering, The University of Adelaide, South Australia (2012)

4. D. S. Miklosovic, M.M. Murray, L.E. Howle, F.E. Fish, Physics of Fluids, 16 (2004)

5. D.S. Miklosovic, M.M. Murray, Journal of Aircraft, 44 (2007)

6. H. Johar, C. Henoch, D. Custodio, A. Levshin, AIAA Journal, 45 (2007)

7. K.L. Hansen, R.M. Kelso, C.J. Doolan, $16^{\text {th }}$ AIAA/CEAS Aeroacoustics Conference (2010)

8. K.L. Hansen, R.M. Kelso, B.B. Dally, AIAA Journal, 49 (2011)

9. J.L.E. Guerreiro, J.M.M. Sousa, AIAA Journal, 50 (2012)

10. K. Hansen, R. Kelso, C. Doolan, , Acoustics Australia, 40 (2012)

11. H. Chen, C. Pan, J. Wang, Science china Technological Sciences, 56 (2013)

12. S. Sudhakar, N. Karthikeyan, The $14^{\text {th }}$ Asian Congress of Fluid Mechanics - 14ACFM October 15 - 19, Hanoi and Halong, Vietnam (2013).

13. I. Zverkov, V. Kozlov, A. Kryukov, Progress in Flight Physics, 5 (2013)
14. M.D. Bolzon, R.M. Kelso, M. Arjomandi, $19^{\text {th }}$ Australasian Fluid Mechanics Conference Melbourne, Australia 8-11 December (2014)

15. M. C. Keerthi, A. Kushari, A. De, A. Kumar, Proceedings of ASME Turbo Expo 2014: Turbine Technical Conference and Exposition, June 16-20, Düsseldorf, Germany (2014)

16. D. Custodio, C.W, Henoch, AIAA Journal, 53, 7 (2015)

17. Z. Wei, T.H. New, Y.D. Cui, , Ocean Engineering, 108 (2015)

18. Z. Wei, T.H. New, Y.D. Cui, The $13^{\text {th }}$ International Symposium on Fluid Control, Measurement and Visualization, November15-18, Doha, Qatar (2015)

19. M.D. Bolzon, R.M. Kelso, M. Arjomandi, J. Aerosp. Eng., 04016085 (2016)

20. M.D. Bolzon, R.M. Kelso, M. Arjomandi, EPJ Web of Conferences, 114 (2016)

21. M.D. Bolzon, R.M. Kelso, M. Arjomandi, Aerospace Science and Technology, 56 (2016)

22. M.C. Keerthi, M.S. Rajeshwaran, A. Kushari, A. De, AIAA Journal, (2016)

23. Z. Wei, B. Zang, T.H. New, Y.D. Cui, Ocean Engineering, 121 (2016)

24. W.J. Chen, W.Y. Qiao, F. Tong, , Acte Aeronautica et Astronautica Sinica, 37 (2016)

25. L.H. Peristy, R.E. Perez, A. Asghar, W.D.E. Allan, $34^{\text {th }}$ AIAA Applied Aerodynamics Conference, 1317 June (2016) Washington, D.C 
26. J. Favier, A. Pinelli, U. Piomelli, Preprint submitted to Elsevier Science, 16 septembre (2011)

27. T. Swanson, K.M. Isaac, $6^{\text {th }}$ AIAA Theoretical Fluid Mechanics Conference, 27-30 June (2011) Honolulu, Hawaii.

28. R.K. Zhang, J.Z. Wu, Wind Energ. 15 (2012)

29. F. Feng, X. Cheng, X. Qi, X. Chang, Applied Mechanics and Materials, 152 (2012)

30. M.J. Kim, H.S. Yoon, J.H. Jung, H.H. Chun, D.W. Park, Int. J Nav Archit Oc Engng, 4 (2012)

31. M.W. Lohry, D. Clifton, L. Martinelli, Seventh International Conference on Computational Fluid Dynamics (ICCFD7), July 9-13, (2012) Big Island, Hawaii

32. A.F. Abdel Gawad, Transaction on control and mechanical systems, 2, 5 (2013)

33. J. F. D. Câmara, $51^{\text {st }}$ AIAA Aerospace Sciences Meeting to be held, 7-10 January (2013), Grapevine, Texas, United States of America.

34. A. Corsini, G. Delibra, A.G. Sheard, Journal of Fluids Engineering, 135 (2013)

35. S.H. Lau, S. Haeri, J.W. Kim, Journal of Sound and Vibration, 332 (2013)

36. A. Skillen, A. Revell, J. Favier, A. Pinelli, U. Piomelli, International symposium on turbulence and shear flow phenomena, August 25-30 (2013) Poitiers, France.

37. Z. Xingwei, S. Graduate, Z. Chaoying, Z. Tao, J. Wenying, Aircraft Engineering and Aerospace Technology: An International Journal, 85 (2013)

38. S.M.A. Aftab, K.A. Ahmad, Applied Mechanics and Materials, 629 (2014)

39. M. Asli, B.M. Gholamali, A.M. Tousi, Hindawi Publishing Corporation Mathematical Problems in Engineering, 493253 (2015)

40. C. Cai, Z. Zuo, S. Liu, Y. Wu, Advances in Mechanical Engineering, 7, 7 (2015)

41. J. Joy, T.H. New, H. Ibrahim, International journal of mechanical aerospace, mechatronic and manufacturing engineering, 10, 2 (2015)

42. D. Serson, J.R. Meneghini, Procedia IUTAM, 14 (2015)

43. C. Cai, Z. Zuo, S. Liu, Y. Wu, International Symposium on Transport Phenomena and Dynamics of Rotating Machinery, Hawaii, Honolulu April 10-15 (2016)

44. C.M. Kobæk, M.O.L. Hansen, Journal of Physics: Conference Series, 753 (2016)

45. N. Rostamzadeh, R.M. Kelso, B. Dally, Theor. Comput. Fluid Dyn., 10 (2016)

46. M. Zhang, M. Zhao, J. Xu, Proceedings of the ASME 2016 International Mechanical Engineering Congress and Exposition, November 11-17 (2016) Phoenix, Arizona, USA.

47. M. Benaissa, I. Ibrahim, T. New, W. Ho, 2017, Topical problems of fluid mechanics, http://www.it.cas.cz/fm/im/im/proceeding/2017/4

48. R.P. Torró, J.W. Kim, Fluid Mech., 813 (2017)

49. M. Zhao, M. Zhang, J. Xu, Engineering applications of computational fluid mechanics, 11, 1 (2017) 